\title{
Students Perspective: The Impact of Podcasts on EFL Students Listening Comprehension
}

\author{
Dinar Ayu Asyifah, Lilia Indriani \\ Tidar University \\ E-mail: dinarayuasy7@gmail.com
}

\begin{abstract}
Technological developments are very beneficial for foreign language learning, even for teachers and students themselves. One of them is the podcast media which has proven to be an easy-to-use and effective means of learning English. The research sample was taken from 30 high school students in Indonesia by using a questionnaire to explore students' perceptions about learning to listen to foreign languages using podcasts. The data collection of this research uses descriptive techniques, namely describing and explaining a phenomenon or case study in schools. Most of the students taken from the questionnaire strongly agreed that podcasts are something that is effective in helping improve listening skills because they are considered to have interesting and fun features that stimulate student enthusiasm and motivate students to continue learning. However, podcasts can prove to be a tool to improve students' listening skills in EFL classes and students recommend teachers to use this media.
\end{abstract}

Keywords: Podcast; EFL; Class; Listening; Students

\section{INTRODUCTION}

As we all know English is compulsory learning for school students at all levels, even English is not only studied by educated people, everyone who has the opportunity to learn English because English has many benefits. This is because English is the language of the world that has the most speakers and is very important to learn as a means of communication and some schools even stipulate that students must be fluent in English as a graduation requirement and also some companies have required their employees to speak English. Even the curriculum in Indonesia has made English a foreign language which is very important for students in schools even those who are not educated. English has four skills, namely listening, speaking, writing and reading. However, this study will discuss listening skills and what effective methods or tools will be used to learn and improve listening comprehension in EFL classes. In fact, listening is one of the English language skills that foreign language learners must train properly because one skill will definitely affect other skills. According to Moeliono (2009: 3), saying that listening means that someone pays attention to what other people say or read and also this will make the speaker and the listener both feel comfortable. Listening also allows people to increase vocabulary, and understanding a 
sentence in a foreign language and listening is not difficult if we find learning tools that are interesting for students. There are three components to listening. The first is understanding, where the listener pays attention to what the speaker is talking about. Second is to hold back, which means that the listener must keep careful what information and messages he gets. Then the last thing is to respond to respond to our understanding of the topic being discussed.

However, the above objectives have not been fully achieved due to several problems faced. The data shows that students are still low in English achievement. Students often get few opportunities to develop English language skills, one of which is listening. Likewise, teachers often lack time to provide language practice learning (Derwing \& Munro, 2013; Verdugo, 2006). In addition, some teachers may be reluctant to teach basic education because of a lack of phonetic training (Weinberg $\&$ Knoerr, 2003). Sometimes students feel bored with learning instructions in the classroom so they are less interested in learning. In fact, Huang (2004) argues that a limited understanding of classroom instruction or lessons and materials can be another problem faced by students in learning English.

Actually, with the development of technology in today's era, people can use it a lot for opportunities to learn and practice foreign languages. Especially now that modern technology now being used in daily life and used by all groups. With technology, a person can learn something independently outside of the classroom or learn together in class and discuss together. The use of multimedia is proven to be very influential and effective for one's learning process. Teaching using technology-based media will make it easier for teachers and students in foreign language classes because it is effective, efficient, and of course more interesting to apply than not using technological media. This means one must have an intermediary to make learning easier. Multimedia is a means to find or convey information that can help to understand (Moreno \& Mayer, 2000, p. 1). Podcasts are multimedia which contain audio and are certainly useful in improving students' listening skills. To control the learning process using podcasts makes it possible to help students learn foreign languages (Lee \& Chan, 2007). It will also help teachers to rearrange class time when teachers are short on time to provide teaching materials to students in class and make podcasts an intermediary for learning and a tool for students to expand their vocabulary, develop verbal or pronunciation skills, and aural (Abdous, Camarena, \& Facer, 2009). Aguilar (2013) states that this can be a good supporting material for students to increase their enthusiasm for learning listening. Even students can become independent learners outside the classroom with free access to choose what topics they like and find interesting to hear. Podcasts are very flexible because they can be used anytime and anywhere, so that students don't feel pressured and can repeat and download the audio, learning activities are no longer limited by time and location (Hew, 2009). Another advantage allows students to make better use of time, productively for constructive learning purposes because there is no time limit when learning to listen using this podcast (Lee \& Chan, 2007). Podcasts are internet audio designed for downloading and listening and this portable device is available on various devices such as 
tabs, smartphones and laptops (Constantine, 2007). In addition, podcasts can be downloaded and played back to improve learning so that students will not feel worried and rushed (Salmon \& Nie, 2008). Podcast facilities can help students to do learning according to their own abilities to get maximum results because of its unlimited access and able to make students feel comfortable when learning to listen. This study was conducted to determine students' opinions about the influence and impact of podcasts on students of English as a foreign language in Indonesia. Data will be taken from 30 high school students who are willing to express their opinions by filling out a questionnaire that the researcher will give.

\section{LITERATURE REVIEW}

Current technological developments are in the teaching and learning process. Recently, several language learning media have been developed. The development of this technology is also very helpful for EFL classes to acquire language. In EFL learning, especially listening skills, some teachers have implemented podcasts as a learning media. Podcasts provide some unique features and a storehouse of real-life speaking that allows students to learn at their own time and pace (Kavaliauskienè, 2008). Even Ahmed (2016) in his study said that podcasts help students to understand and develop content in language teaching. This study discusses the benefits of a podcast as a learning media and students' responses to learning using podcasts.

\section{Teaching Listening}

Listening trains how we absorb information and messages and even trains us to pronounce correct pronunciation in a language, this is the reason why listening is one of the four important skills. Listening can be done by students directly or through intermediary media such as audio-based podcasts and flexibility. Listening makes teachers have to have principles and strategies in teaching students because teachers are very influential on students' understanding, such as materials and learning media that are effectively used so that they do not deviate from the learning objectives because there are still too many teachers giving too much random material such as spending one CD in one time. In addition, students must also get used to using podcasts to maximize their abilities. It would be better if students write down their difficulties when studying and then discuss and discuss together in class. A student must learn English just like when a baby learns his mother tongue so that his understanding is mature. In learning listening, teachers must find ways that allow students to learn easily, pleasantly, and can achieve learning goals. Teaching listening via audio is a great tool to do and suitable for beginners with a wider range of material.

\section{Use Podcast in English Teaching}

Podcasts will look like radio where both are audio-based tools, it's just that podcasts can be downloaded and listened to anytime and anywhere with access to different topics and can be chosen as freely as possible by listeners while radio is not like that. This makes it easier for students who want to repeat learning material especially for students who find it difficult to understand the material in a short time because the level and way of understanding a child is certainly different. Podcasts provide listeners 
with access to select audio broadcasts that they like according to their convenience and will feel more practical so that students will not feel overwhelmed when learning to listen and will be better if it is continued with class discussions which will surely arouse students' enthusiasm for learning and knowing something. Even podcasts provide audio broadcasts in various languages, one of which is English which is the language most widely used, because this is why students can also remember and record vocabulary, information, and also know how to pronounce a word correctly. Constantine (2007) explains the importance of using podcasts in foreign language learning from beginners to advanced, this means that podcasts can be used by all people. Podcasts are also used as a major source of positive impact in EFL classrooms, which will make the classroom more enjoyable and the student impressed. Hawke's (2010) explains that one of the ways to improve students' English listening skills is through podcasts.

\section{METHOD}

\section{Population and Sampel}

This study was conducted to determine students' opinions about the influence and impact of podcasts on students in Indonesia for those who have learned to listen in EFL classes using podcasts as a tool to improve their understanding. Data will be taken from 30 high school students who are willing to express their opinions through a questionnaire in order to see how far the influence of podcasts is on students, what are the most prominent advantages, and what difficulties students have faced learning listening using podcasts.

\section{Data Collecting Technique}

Data taken from experiences in the classroom. The data were collected from instruments in 10 items from the questionnaire survey which was used to find out students' perspectives while learning English using podcasts. According to Sugiyono (2010, p. 199) a questionnaire is a data collection technique by giving several written questions to respondents. This technique is relatively efficient and fast for obtaining large amounts of information. In addition to using a questionnaire, researchers will conduct interviews with students. Moleong (2017, p. 135) argues that an interview is where the researcher and the respondent come face to face to obtain information verbally and can explain the researcher's problems. 


\section{FINDINGS AND DISCUSSION Result of Questionnaire}

Table : Students rating of their use of podcast

\begin{tabular}{|r|l|r|r|r|r|r|}
\hline \multirow{2}{*}{ No } & & \multicolumn{3}{|c|}{ Respons } \\
\cline { 3 - 6 } & & $\begin{array}{c}\text { Questions } \\
\text { Agree }\end{array}$ & Agree & Neutral & Disagree & $\begin{array}{c}\text { Strongly } \\
\text { Disagree }\end{array}$ \\
\hline 1. & I feel that my listening skill improve after listening to Podcast & $0 \%$ & $69,2 \%$ & $23,1 \%$ & $7,7 \%$ & $0 \%$ \\
\hline 2. & Using podcast enhance my motivation in learning English & $7,7 \%$ & $76,9 \%$ & $15,4 \%$ & $0 \%$ & $0 \%$ \\
\hline 3. & I found a difficult to understand what the speaker says & $46,2 \%$ & $15,4 \%$ & $38,5 \%$ & $0 \%$ & $0 \%$ \\
\hline 4. & Podcast offer authentic materials of English listening & $8,3 \%$ & $33,3 \%$ & $58,3 \%$ & $0 \%$ & $0 \%$ \\
\hline 5. & The task and activities in podcast are interesting & $7,7 \%$ & $42,2 \%$ & $42,2 \%$ & $0 \%$ & $0 \%$ \\
\hline 6. & Podcast is very portable and easy to use & $7,7 \%$ & $53,8 \%$ & $38,5 \%$ & $0 \%$ & $0 \%$ \\
\hline 7. & Podcast is not effective in terms of time & $0 \%$ & $25 \%$ & $75 \%$ & $0 \%$ \\
\hline 8. & Podcast duration is appropriate for us to concentrate on listening & $0 \%$ & $76,9 \%$ & $23,1 \%$ & $0 \%$ \\
\hline 9. & My vocabulary is enriched after listening to podcast & $7,7 \%$ & $76,9 \%$ & $15,4 \%$ & $0 \%$ \\
\hline 10. & I recommend teacher to use podcast in teaching listening & $7,7 \%$ & $53,8 \%$ & $38,5 \%$ & $0 \%$ & $0 \%$ \\
\hline
\end{tabular}

From the questionnaire above, it seems that podcasts can improve listening skills, although $7.7 \%$ disagreed. Meanwhile, $84.6 \%$ of students (strongly agree and agree) feel podcasts can increase motivation to learn English and some think they are neutral. But it seems that there are things that are considered the most difficult by students and get the highest percentage of strongly agree, namely students who still find it difficult with what the speaker said on the podcast. There are $41.6 \%$ of students who feel podcasts are right to provide auntentic listening material and some choose neutral. In addition, the students all agree that podcasts are an interesting and easy to use media. But somehow $25 \%$ of students choose that podcast is not effective in terms of time. Most importantly, all students also agree that podcasts can add to their vocabulary and recommend teachers to use podcasts as a media for language learning. The point is that very few students find it difficult when they try to understand what the speaker is talking about, besides that all of them give a positive response to podcasts as a learning media.

The results above indicate that of course the podcast affects students' listening ability. The scores above prove podcasts to be an effective tool for improving listening skills. The above proves that podcasts have a positive impact on speaking English. Even some students strongly agree that podcasts are a media that can improve their listening skills. Same as other research results that prove that podcasts have a better performance in listening than those who don't use podcasts (Kavaliauskienè, 2008; Qasim \& Fadda, 2013) (Ahmed, 2016). Apart from that, the students agreed that the podcast increased their motivation 
to learn English. Podcasts that provide features provide enthusiasm for students so that it creates high motivation. Podcasts are unique and interesting media to use according to them and can also be used anytime and anywhere. Student motivation can be seen from student enthusiasm when using podcast media. According to Morris (2010) podcast provides students with an understanding of listening where students use their imaginations and describe what they hear.

However, in the questionnaire, unfortunately, students strongly agreed that they found it difficult to understand what the speaker was talking about. The solution is to train students to listen to material they think is easy first and not push it. Then over time they will increase their level in the listening material. Podcasts provide a lot of material even for beginners who are just learning a foreign language to those who are already familiar with a foreign language. In the podcast, students are also given the opportunity to freely choose which material they are interested in listening to. The most important thing is that no students find it difficult to use podcasts. There are so many learning platforms that make it difficult for students to use them to learn. But for podcasts they agree that this is an effective and easy to use media.

Students have the opportunity to add vocabulary to listening material (Putman \& Kingsley, 2011). This is in line with the results of previous research that podcasts can actually increase students' vocabulary. According to Chan, Chi, Chin, \& Lin (2018) students can add vocabulary because they access podcasts according to their interests. Students get excited when they listen to a different topic from this podcast that increases students' vocabulary. In addition, interesting activities such as discussions and group competitions to answer listening assignments. Without realizing it, podcasts can also make someone think critically and creatively. With the flexibility of a podcast, students say they can use it outside of the classroom and even download it, which helps them find podcasts immensely. In fact, not only students who find it easy to use but teachers will also find it as a teacher, teachers no longer nee to be confused about topics because podcasts have very broad topics for everyone to access.

Podcasts make students more imaginative, increase vocabulary, and get new lessons even those that are difficult to find in the classroom (Lee \& Chan, 2007). Students also strongly agree that teachers use podcasts as a learning media because this will stimulate students' enthusiasm with its interesting and easy to use features. The results revealed that podcasts can improve students' listening skills in EFL classes. The conclusion is that podcasts are a reliable and relevant tool for teachers and students to use to improve the vocabulary of students in EFL classrooms.

\section{CONCLUSION}

The findings of this study have a positive response from students in improving listening skills in EFL classes. More precisely, they agree that podcasts are an effective tool to use in learning. Its attractive and easy-to-use features will generate enthusiasm and motivation for students to learn. In addition, this media is very easy to use and can be used outside the classroom. Also the teacher students use podcasts as 
a media for learning to listen because they get a lot of words from the podcast.

\section{LIMITATION OF THE STUDY}

This study has some limitations within which our findings need to be intrepeted carefully. First, the research presented here was limited by the measures used. Second, our study was cross-sectional in nature and assessed respondent perception of the obligation at a specific time. Last, result of this study may not be completely generalizable.

\section{SUGGESTIONS FOR FURTHER RESEARCH}

Researchers have several suggestions for further researchers, as follows:

1. Limited research results must make further research must have complete results

2. Further research can find more respondents so that the results can be more satisfying to readers

3. Other researchers can use good qualitative methods to develop research results

\section{REFERENCES}

Abdous, M., Camarena, M. M., \& Facer, B. R. (2009). MALL technology: Use of academic podcasting in the foreign language classroom. ReCALL: The Journal of EUROCALL (European Association for Computer Assisted Language Learning), 21(1), 76.

Aguilar, F. R. (2013). Podcasting for language learning through iTunes U: The learner's view. Language Learning \& Technology, 17(3), 74-93.

Chan, W. M., Chi, S. W., Chin, K. N., \& Lin, C. Y. (2018). Students' Perceptions of and Attitudes towards Podcast-Based Learning - A Comparison of
Two Language Podcast Projects. Electronic Journal of Foreign Language Teaching, 8(1), 312-335.

Constantine, P. (2007). Podcasts: another source for listening input. The Internet TESL Journal, 13(1).

Derwing, T. M., \& Munro, M. J. (2013). The development of L2 oral language skills in two L1 groups: A 7-year study. Language Learning 63.2 (2013), 63(2), 163-185.

Hawke, P. (2010). Using Internet-Sourced Podcasts In Independent Listening Course: Legal And Pedagogical Implications. Jalt CALL Journal, 6(3), 219-234.

Hew, K. F. (2009). Use of audio podcast in K-12 and higher education: A review of research topics and methodologies. Educational Technology Research and Development, 57(3), 333-357.

Huang, J. (2004). Voices From Chinese Students: Professors'use Of Englishaffects Academic Listening. College Student Journal, 38(2).

Kavaliauskiené, G. (2008). Podcasting: a tool for improving listening skills. Teaching English with Technology, 8(4).

Lee, M. J., \& Chan, A. (2007). Pervasive, LifestyleIntegrated Mobile Learning For Distance Learners: An Analysis And Unexpected Results From A Podcasting Study. Open Learning: The Journal of Open, Distance and e-Learning, 22(3), 201-218.

Moleong, L. J. (2017). Metode Penelitian Kualitatif. Bandung: PT Remaja Rosdakarya.

Moreno, R., \& Mayer, R. E. (2000). A learner-centered approach to multimedia explanations: Deriving instructional design principles from cognitive theory. Interactive Multimedia Electronic Journal of Computer-Enhanced Learning, 2(2), 12-20.

Morris, N. P. (2010). The Atoms Family: Using Podcasts to Enhance the Development of Science Vocabulary. Bioscience Education, 16(1), 1-7.

Putman, S. M., \& Kingsley, T. (2011). The atoms family: Using podcasts to enhance the development of science vocabulary. The Reading Teacher, 63(2), 100-108. 
Qasim, N. Al, \& Fadda, H. Al. (2013). From Call to Mall: The Effectiveness of Podcast on EFL Higher Education Students' Listening Comprehension. English Language Teaching, 6(9), 30-41.

Salmon, G., \& Nie, M. (2008). Doubling the life of iPods. Podcasting for Learning in Universities, 1-11. Retrieved from https://www.academia. edu/17505987/Doubling_the_life_of_iPods

Sugiyono. (2010). Metode Penelitian Kuantitatif, Kualitatif, dan R\&D. Bandung: Alfabeta.

Verdugo, D. R. (2006). A study of intonation awareness and learning in non-native speakers of English. Language Awareness, 15(3), 141-159.
Weinberg, A., \& Knoerr, H. (2003). Learning French pronunciation: Audiocassettes or multimedia? Calico Journal, 20(2), 315-336.

\section{Authors' Brief CV}

Dinar Ayu Asyifah. Student of English Education, Faculty of Teacher Training and Education at Tidar University, semester 5 .

Lilia Indriani. Lecturer in English Department, Faculty of Education and Teacher Training, Universitas Tidar. Her interest is on Technology Enhance Language Learning and Theories and Principles in Teaching English as Foreign Language. 